\title{
PRAWO KOŚCIOŁA KATOLICKIEGO DO ZAKŁADANIA I PROWADZENIA SZKÓŁ
}

Prawo do nauki jest jednym $\mathrm{z}$ podstawowych praw człowieka. W polskim systemie prawnym, na mocy art. 70 ust. 1 Konstytucji Rzeczypospolitej Polskiej ${ }^{1}$ zostało ono zagwarantowane każdemu człowiekowi. Oświata jest dziedziną, za którą odpowiedzialne jest państwo. W Polsce obowiązek prowadzenia szkół w głównej mierze powierzony został jednostkom samorządu terytorialnego. Jednak pomimo tego, że edukacja publiczna należy do zadań własnych gminy ${ }^{2}$, powiatu $^{3}$ i województwa ${ }^{4}$, w realizacji zadań oświatowych podmioty

* S. mgr lic., Wydział Prawa, Prawa Kanonicznego i Administracji, Katolicki Uniwersytet Lubelski Jana Pawła II, Al. Racławickie 14, 20-950 Lublin, e-mail: katesw@student. kul.lublin.pl

${ }^{1}$ Konstytucja Rzeczypospolitej Polskiej z dnia 2 kwietnia 1997 r. (Dz. U. Nr 78, poz. 483 z późn. zm.).

${ }^{2}$ Art. 7 ust. 1 pkt 8 ustawy z dnia 8 marca 1990 r. o samorządzie gminnym (Dz. U. z 2001 r. Nr 142, poz. 1591, z późn. zm.).

${ }^{3}$ Art. 4 ust. 1 pkt 1 ustawy z dnia 5 czerwca 1998 r. o samorządzie powiatowym (Dz. U. z 2001 r. Nr 142, poz. 1592 z późn. zm.); D. Kurzyna-Chmiel, Podstawy prawne i organizacyjne oświaty. Prawo oświatowe w zarysie, Warszawa 2009, s. 107: „Pomimo iż w ustawie tej nie ma rozróżnienia na zadania własne i zlecone, kategorie zadań własnych można wyinterpretować $\mathrm{z}$ art. 166 ust. 1 Konstytucji RP zgodnie z którym zadania publiczne służące zaspokajaniu potrzeb wspólnoty samorządowej są wykonywane przez jednostki samorządu terytorialnego jako zadania własne".

${ }^{4}$ Art. 14 ust. 1 pkt 1 ustawy z dnia 5 czerwca 1998 r. o samorządzie województwa (Dz. U. z 2001 r. Nr 142, poz. 1590 z późn. zm.). 
te wspierane są przez podmioty prywatne, również przez podmioty kościelne.

\section{DZIAŁALNOŚĆ OŚWIATOWA W MISJI KOŚCIOŁA KATOLICKIEGO}

Duże zasługi w dziedzinie oświaty przypisywane są Kościołowi katolickiemu ${ }^{5}$. Jego dynamiczna działalność edukacyjna, prowadzona od czasów średniowiecza, zdecydowanie wpłynęła na rozwój szkolnictwa w Europie. Do czasów Rewolucji Francuskiej prekursorami w zakładaniu i prowadzeniu szkół były jednostki organizacyjne Kościoła katolickiego ${ }^{6}$. Pomimo przejęcia przez poszczególne państwa odpowiedzialności za realizację zadań oświatowych, szkoły prowadzone przez kościelne osoby prawne są nadal cenione ze względu na poziom nauczania i przekazywane wartości.

U podstaw prawa i obowiązku Kościoła katolickiego do nauczania znajduje się misja obwieszczania misterium zbawienia wszystkim ludziom oraz troska o integralny rozwój każdego człowieka ${ }^{7}$. Jednym ze sposobów wypełniania przez Kościół tej misji jest prowadzenie szkolnictwa katolickiego. Zgodnie z kan. 803 § 1 KPK/1983 „szkołę wtedy uważa się za katolicką, gdy jest kierowana przez kompetentną władzę kościelną albo kościelną osobę prawną publiczną, albo za katolicką została uznana przez władzę kościelną dokumentem na piśmie”. Wyróżnić można zatem szkoły, które prawo kanoniczne uznaje za katolickie ze względu na podmiot prowadzący - władzę kościelną lub kościelną

${ }^{5}$ J. Wroceński, Sytuacja prawna szkolnictwa wyznaniowego w III Rzeczypospolitej Polskiej, w: Ecclesia et status. Księga jubileuszowa z okazji 40-lecia pracy naukowej Profesora Józefa Krukowskiego, red. A. Dębiński, K. Orzeszyna, M. Sitarz, Lublin 2004, s. 961.

${ }^{6} \mathrm{~K}$. Warchałowski, Nauczanie religii i szkolnictwo katolickie $w$ konkordatach współczesnych, Lublin 1998, s. 121.

${ }^{7}$ Codex Iuris Canonici auctoritate Ioannis Pauli PP. II promulgatus, AAS 75(1983) II, s. 1-317, Kodeks Prawa Kanonicznego, przekład polski zatwierdzony przez Konferencję Episkopatu, Poznań 1983 (dalej: KPK/1983), kan. 794 § 1 „Z szczególnej racji prawo i obowiązek wychowania należy do Kościoła, któremu została zlecona przez Boga misja niesienia ludziom pomocy, aby mogli osiągnąć pełnię życia chrześcijańskiego. § 2 Do duszpasterzy należy obowiązek czynić wszystko, ażeby wszyscy wierni mogli otrzymać katolickie wychowanie". 
osobę prawną publiczną oraz szkoły, prowadzone przez inne podmioty prawne, uznane za katolickie na mocy dokumentu wydanego przez kompetentną władzę kościelną. Szkoły prowadzone przez kościelne osoby prawne publiczne ${ }^{8}$, nawet jeśli w swej nazwie nie posiadają przymiotnika „katolicka”, są zgodnie z Kodeksem Prawa Kanonicznego szkołami katolickimi. Z kolei szkoły prowadzone przez kościelne osoby prawne prywatne ${ }^{9}$ lub przez osoby fizyczne, posiadające pełną zdolność do czynności prawnych ${ }^{10}$, mogą być uznane za katolickie na mocy dokumentu wydanego przez kompetentną władzę kościelną ${ }^{11}$.

Tożsamość szkoły katolickiej wyraża się przede wszystkim w trosce o integralny rozwój wychowanków ${ }^{12}$, zgodny z chrześcijańską koncepcją człowieka, u podstaw której stoi Osoba Jezusa Chrystusa i wartości ewangeliczne ${ }^{13}$. Realizacja tych zadań możliwa jest dzięki zaangażowaniu nauczycieli świadomych szczególnej misji, nie tylko przekazywania wiedzy, ale również kształtowania postaw powierzonych ich opiece dzieci i młodzieży, a przede wszystkim dawania świadectwa

${ }^{8}$ Kościelne osoby prawne publiczne osobowość prawnokanoniczną otrzymują ipso iure lub specjalnym dekretem kompetentnej władzy. „Są ustanowione przez kompetentną władzę kościelną, by wykonywały w imieniu Kościoła, w oznaczonym dla nich zakresie, zgodnie z przepisami prawa, własne zadania im zlecone dla publicznego dobra" (kan. 116 KPK/1983); R. Sobański, Osoby fizyczne i prawne, w: Komentarz do Kodeksu Prawa Kanonicznego. Tom I. Księga I. Normy ogólne, red. J. Krukowski, R. Sobański, Poznań 2003, s. 192-193.

${ }^{9}$ Kościelne osoby prawne prywatne osobowość prawnokanoniczną nabywają poprzez specjalny dekret władzy kościelnej. Zob. kan. 116 § KPK/1983; R. Sobański, Osoby fizyczne i prawne, s. 193.

${ }^{10}$ Kan. 96 i 98 KPK/1983; R. Sobański, Osoby fizyczne i prawne, s. 166.

${ }^{11}$ Kan. 803 KPK/1983; L. Chiappetta, Il Codice di Diritto Canonico. Commento giuridico-pastorale, Napoli 1988, s. 885; D. Composta, Commento al can. 803, w: Commento al Codice di Diritto Canonico, red. P.V. Pinto, Città del Vaticano 2001, s. 499.

${ }^{12}$ II Polski Synod Plenarny, Szkoła i uniwersytet w życiu Kościoła i narodu, w: II Polski Synod Plenarny (1991-1999), Poznań 2001, n. 14.

${ }^{13}$ Congregazione per l'Educazione Cattolica, La scuola cattolica alle soglie del terzo millennio, 28.12.1997, w: Enchiridion Vaticanum, vol. 16, s. 1570-1583; tekst polski: Kongregacja ds. Wychowania Katolickiego, Szkoła katolicka u progu trzeciego tysiąclecia, w: Stużyć wzrastaniu w prawdzie i miłości. Wybór dokumentów Kościoła na temat szkoły katolickiej i wychowania, red. J. Poniewierski, Kraków 2009, s. 483-494, n. 9; Z. Grocholewski, Osoby konsekrowane i ich misja w szkolnictwie, „L'Osservatore Romano” wyd. pol., 3(2003), s. 46; T. Zasępa, Szkoła katolicka w XXI wieku, w: Szkoła katolicka w XXI wieku, red. T. Zasępa, Lublin 2003, s. 17. 
tym wartościom, które przekazują ${ }^{14}$. Prawodawca kościelny w kan. 803 $\S 2 \mathrm{KPK} / 1983$ podkreśla, że nauczyciele w szkołach katolickich mają odznaczać się zdrową nauką i prawością życia, od nich bowiem w znacznej mierze zależy utrzymywanie charakteru katolickiego szkoły. Powinni oni również podejmować dialog z rodzicami ${ }^{15}$, jako tymi, którym przysługuje pierwszeństwo w wychowaniu dzieci. Ważne jest, aby nauczyciele szkół katolickich swoje posłannictwo spełniali w przekonaniu, że uczestniczą w wychowawczej misji Kościoła ${ }^{16}$.

Zachowanie przez szkołę katolicką chrześcijańskiej tożsamości jest bardzo istotną kwestią, nie wyklucza jednak edukacji w takiej szkole uczniów niekatolików, o ile tylko ,zaakceptują i podejmą oni przyjętą ofertę programową"17. Na obecność w szkołach katolickich uczniów niebędących katolikami zwrócono uwagę w deklaracji o wychowaniu chrześcijańskim Gravissimum educationis ${ }^{18}$. Początkowo zjawisko to dotyczyło przede wszystkim terenów misyjnych ${ }^{19}$. Z upływem jednak czasu, wobec rosnącego zróżnicowania społeczeństw pod względem

${ }^{14}$ Congregazione per l'Educazione Cattolica, Il laico cattolico testimone della fede nella scuola, 15.10.1982, w: Enchiridion Vaticanum, vol. 8, s. 262-341; tekst polski: Kongregacja ds. Wychowania Katolickiego, Świecki katolik świadkiem wiary w szkole, w: Stużý́ wzrastaniu w prawdzie i miłości, s. 395-430, n. 1; Jan Paweł II, Zadania szkoły katolickiej dzisiaj. Przemówienie do uczestników Międzynarodowego Kongresu Katolickich Szkót Europy, Rzym, 28.04.2001, w: Stużyć wzrastaniu w prawdzie i miłości, s. 328.

${ }^{15}$ Kongregacja ds. Wychowania Katolickiego, Szkoła katolicka u progu trzeciego tysiąclecia, n. 20: „Niezmiennym celem wychowania szkolnego jest więc spotkanie i dialog z rodzicami i rodziną, trzeba go popierać również poprzez promocję stowarzyszeń rodzicielskich, ażeby z ich niezastąpionym udziałem nawiązała się owa osobista relacja, która pozwala urzeczywistnić założenia wychowawcze".

${ }^{16}$ Kongregacja ds. Wychowania Katolickiego, Świecki katolik świadkiem wiary w szkole, n. 24; Joannes Paulus II, Adhortatio apostolica post-synodalis de vocatione et missione laicorum in Ecclesia et in mundo Christifideles laici, 30.12.1988, AAS 81(1989), s. 393-521, tekst polski: Jan Paweł II, Adhortacja apostolska Christifideles laici o powołaniu i misji świeckich w Kościele i w świecie, w: Adhortacje Ojca Świętego Jana Pawła II, t. I, Kraków 1997, s. 271-377, n. 62.

${ }^{17}$ Kongregacja ds. Wychowania Katolickiego, Szkoła katolicka u progu trzeciego tysiąclecia, n. 16.

${ }^{18}$ Sacrosanctum Concilium Oecumenicum Vaticanum II, Declaratio de educatione christiana Gravissimum educationis, 28.10.1965, AAS 58(1966), s. 728-739, tekst polski: Sobór Watykański II, Deklaracja o wychowaniu chrześcijańskim Gravissimum educationis, w: Sobór Watykański II, Konstytucje Dekrety Deklaracje, Poznań 2002, s. 314-324.

${ }^{19}$ Tamże, n. 9. 
narodowym, etnicznym i religijnym, rozszerzyło się, a powierzone szkołom katolickim zadanie wychowywania do odważnego wyznawania swojej wiary, z zachowaniem szacunku wobec innych, stało się szczególnie istotne. Nawiązując do tego zagadnienia, papież Benedykt XVI w przemówieniu skierowanym do uczestników Zgromadzenia Plenarnego Kongregacji ds. Wychowania Katolickiego, których przyjął w dniu 21 stycznia 2008 r. w Sali Klementyńskiej Pałacu Apostolskiego podkreślił, że powszechny dostęp do szkół katolickich, ich otwartość dla wszystkich i poszanowanie tożsamości każdego, nie może powodować rezygnacji z proponowania własnej perspektywy wychowawczej, ludzkiej i chrześcijańskieje ${ }^{20}$.

W ostatnim czasie na problematykę odpowiedzialności i wkładu szkół katolickich w kształtowanie mentalności jedności i szacunku w różnorodności, opartych na wartościach ewangelicznych, zwróciła uwagę Kongregacja ds. Wychowania Katolickiego w dokumencie z dnia 28 października 2013 r. Educare al dialogo interculturale nella scuola cattolica. Vivere insieme per una civiltà dell'amore (Wychowanie do dialogu międzykulturowego w szkole katolickiej. Żyć razem dla cywilizacji miłości $)^{21}$. Podkreślono w nim m.in. potrzebę wychowywania do dialogu z odmiennymi wizjami życia, z zachowaniem własnej tożsamości szkoły katolickiej, tożsamości wynikającej z wiary w Chrystusa i przynależności do Kościoła. Wezwanie do umocnienia tożsamości szkoły katolickiej wobec rosnącego zjawiska pluralizmu kulturowego i religijnego zawarte zostało również w dokumencie roboczym Educare oggi e domani. Una passione che si rinnova (Wychowywać dziś i jutro. Pasja, która się odnawia) z dnia 7 kwietnia 2014 r., przygotowanym przez Kongregację ds. Wychowania Katolickiego ${ }^{22}$. Dokument ten stanowi przygotowanie do światowego spotkania, które odbędzie się w dniach 18-21 listopada 2015 r. w Rzymie, z okazji 50. roczni-

${ }^{20}$ Benedykt XVI, Przemówienie do uczestników sesji plenarnej Kongregacji do spraw Wychowania Katolickiego, Rzym, 21 stycznia 2008, w: Stużyć wzrastaniu w prawdzie i miłości, s. 345-346.

${ }^{21} \mathrm{http} / / /$ www.vatican.va/roman_curia/congregations/ccatheduc/documents/rc_con_ccatheduc_doc_20131028_dialogo-interculturale_it.html [dostęp: 01.09.2014].

${ }^{22} \mathrm{http}: / /$ www.vatican.va/roman_curia/congregations/ccatheduc/documents/rc con ccatheduc_doc_20140407_educare-oggi-e-domani_it.html [dostęp: 04.09.2014]. 
cy podpisania deklaracji o wychowaniu chrześcijańskim Gravissimum educationis i 25. rocznicy konstytucji apostolskiej o uniwersytetach katolickich Ex corde Ecclesiae ${ }^{23}$. Dokument zawiera wyzwania duszpasterskie oraz prawne i może stanowić pomoc w weryfikacji działalności oświatowej podmiotów kościelnych, jak również w odnowieniu pasji wychowawczej i wzmożeniu formacji osób zatrudnionych w katolickich szkołach i uniwersytetach.

$\mathrm{Na}$ poziomie lokalnym - diecezjalnym za wspieranie inicjatywy zakładania szkół, w których przekazywane byłoby wychowanie w duchu chrześcijańskim, odpowiedzialny jest biskup diecezjalny. Gdyby na terenie jego diecezji nie było tego rodzaju szkół, powinien on podjąć działania w celu ich powstania ${ }^{24}$. W kan. 806 KPK/1983 prawodawca kościelny stanowi również, że biskup diecezjalny ma prawo czuwać nad szkołami położonymi na jego terytorium, a także wizytować $\mathrm{je}^{25}$, stanowią one bowiem istotny element duszpasterskiego oddziaływania.

\section{PODMIOTY UPRAWNIONE DO PROWADZENIA SZKÓŁ KATOLICKICH}

Polski prawodawca prawo do prowadzenia szkół przyznaje szerokiemu kręgowi podmiotów. Są wśród nich podmioty państwowe, samorządowe oraz inne osoby prawne i fizyczne. Na uprawnienie obywateli i instytucji do zakładania szkół wskazuje art. 70 ust. 3 Konstytucji RP, jeśli natomiast chodzi o kwestie szczegółowe, to regulują je przepisy ustawy z dnia 7 września 1991 r. o systemie oświaty ${ }^{26}$. Zgodnie z art. 5 ust. 2 i ust. 3a-3f wskazanej ustawy, podmiotami uprawnionymi do zakładania i prowadzenia szkół są: jednostki samorządu terytorialne-

${ }^{23}$ Joannes Paulus II, Constitutio apostolica Ex corde Ecclesiae de universitatibus catholicis, 15.08.1990, AAS 82(1990), s. 1475-1509, tekst polski: Jan Paweł II, Konstytucja apostolska o uniwersytetach katolickich Ex corde Ecclesiae, „L'Osservatore Romano”, wyd. pol., 10-11(1990), s. 5-9.

${ }^{24}$ Kan. 802 \& $1 \mathrm{KPK} / 1983$.

${ }^{25}$ Kan. 806 KPK/1983; D. Composta, Commento al can. 806, w: Commento al Codice di Diritto Canonico, red. P.V. Pinto, Città del Vaticano 2001, s. 500.

${ }^{26}$ Dz. U. z 2004 r. Nr 256, poz. 2572 z późn. zm. 
go, inne osoby prawne, osoby fizyczne, a także ministrowie właściwi do spraw wewnętrznych, do spraw oświaty i wychowania, do spraw kultury i ochrony dziedzictwa narodowego, do spraw rolnictwa oraz Minister Obrony Narodowej. W związku z tym, że szkoły nie posiadają osobowości prawnej, warunkiem niezbędnym jest posiadanie jej przez podmioty, które ubiegają się o założenie szkoły. Należy zatem stwierdzić, że jednostki organizacyjne nieposiadające osobowości prawnej, jak również osoby fizyczne, które nie mają pełnej zdolności do czynności prawnych, rozumianej jako nieograniczona dyspozycja do nabywania we własnym imieniu praw i obowiązków z zakresu prawa cywilnego, czyli osoby małoletnie, ubezwłasnowolnione całkowicie lub częściowo $^{27}$, nie mogą być organami prowadzącymi szkołę.

Wśród podmiotów, które mogą zakładać i prowadzić szkoły ustawa oświatowa nie wyróżnia związków wyznaniowych. Posiadanie przez kościoły i inne związki wyznaniowe osobowości prawnej pozwala jednak zaliczyć je do wskazanej w ustawie grupy innych niż jednostki samorządu terytorialnego osób prawnych, uprawnionych do prowadzenia działalności oświatowej. Osobowość prawną związki wyznaniowe w Polsce mogą nabywać poprzez wpis do rejestru kościołów i innych związków wyznaniowych ${ }^{28}$ albo na mocy odrębnej ustawy, regulującej sytuację prawną danego związku wyznaniowego ${ }^{29}$, której to ustawie - w przypadku Kościoła katolickiego - towarzyszy umowa międzynarodowa zawarta ze Stolicą Apostolską ${ }^{30}$. W związku z brakiem wyróżnienia kościelnych osób prawnych w ustawie o systemie oświaty, zakładanie szkół przez te podmioty odbywa się na podstawie przepisów

${ }^{27}$ S. Dmowski, Komentarz do art. 8 ( $n r$ 1), w: Komentarz do kodeksu cywilnego. Księga pierwsza. Cześć ogólna. Tytut II. Osoby, red. S. Dmowski, S. Rudnicki, Warszawa 2004, s. 66-71.

${ }^{28}$ Rejestracji związków wyznaniowych poświęcony jest Dział III ustawy z dnia 17 maja 1989 r. o gwarancjach wolności sumienia i wyznania (tekst jedn. Dz. U. z 2005 r. Nr 231, poz. 1965 z późn. zm.) oraz wydane na jej podstawie rozporządzenie Ministra Spraw Wewnętrznych i Administracji z dnia 31 marca 1999 r. w sprawie rejestru kościołów i innych związków wyznaniowych (Dz. U. Nr 38, poz. 374).

${ }^{29}$ H. Misztal, Wprowadzenie do prawa wyznaniowego, w: Prawo wyznaniowe, red. A. Mezglewski, H. Misztal, P. Stanisz, Warszawa 2011, s. 4-5.

${ }^{30}$ Konkordat między Stolicą Apostolską i Rzecząpospolitą Polską, podpisany dnia 28 lipca 1993 r., ratyfikowany dnia 23 lutego 1998 r. (Dz. U. z 1998 r. Nr 51, poz. 318). 
ogólnych, dotyczących osób prawnych innych niż jednostki samorządu terytorialnego.

Warto zwrócić uwagę, że prowadzenie szkół nie jest wyłączną domeną Kościoła katolickiego. Prawo poszczególnych związków wyznaniowych do prowadzenia szkół, expressis verbis wyrażone zostało $\mathrm{w}$ jedenastu ustawach indywidualnych ${ }^{31}$. Prawo do prowadzenia szkół w przypadku pozostałych związków wyznaniowych, o ile posiadają osobowość prawną, która jest warunkiem sine qua non założenia szkoły, wskazane zostało w art. 21 ust. 1 ustawy z dnia 17 maja 1989 r. o gwarancjach wolności sumienia i wyznania.

Wśród szkół prowadzonych przez podmioty wyznaniowe w Polsce najliczniejszą grupę stanowią szkoły katolickie, co odzwierciedla strukturę wyznaniową społeczeństwa. W polskim systemie prawnym jednak pojęcie „szkoła katolicka” nie występuje ${ }^{32}$, pojawia się ono natomiast $\mathrm{w}$ literaturze ${ }^{33}$ i najczęściej oznacza szkoły prowadzone

${ }^{31}$ Art. 20 ustawy z dnia 17 maja 1989 r. o stosunku Państwa do Kościoła Katolickiego w Rzeczypospolitej Polskiej (Dz. U. z 2013 r., poz. 1169 z późn. zm.), art. 16 ustawy z dnia 4 lipca 1991 r. o stosunku Państwa do Polskiego Autokefalicznego Kościoła Prawosławnego (Dz. U. Nr 66, poz. 287 z późn. zm.), art. 16 ustawy z dnia 13 maja 1994 r. o stosunku Państwa do Kościoła Ewangelicko-Augsburskiego w Rzeczypospolitej Polskiej (Dz. U. Nr 73, poz. 323 z późn. zm.), art. 14 ustawy z dnia 30 czerwca 1995 r. o stosunku Państwa do Kościoła Ewangelicko-Metodystycznego w Rzeczypospolitej Polskiej (Dz. U. Nr 97, poz. 479 z późn. zm.), art. 13 ustawy z dnia 30 czerwca 1995 r. o stosunku Państwa do Kościoła Chrześcijan Baptystów w Rzeczypospolitej Polskiej (Dz. U. Nr 97, poz. 480 z późn. zm.), art. 13 ustawy z dnia 30 czerwca 1995 r. o stosunku Państwa do Kościoła Adwentystów Dnia Siódmego w Rzeczypospolitej Polskiej (Dz. U. Nr 97, poz. 481 z późn. zm.), art. 11 ustawy z dnia 30 czerwca 1995 r. o stosunku Państwa do Kościoła Polskokatolickiego w Rzeczypospolitej Polskiej (Dz. U. Nr 97, poz. 482 z późn. zm.), art. 13 ustawy z dnia 20 lutego 1997 r. o stosunku Państwa do gmin wyznaniowych żydowskich w Rzeczypospolitej Polskiej (Dz. U. Nr 41, poz. 251 z późn. zm.), art. 11 ustawy z dnia 20 lutego 1997 r. o stosunku Państwa do Kościoła Mariawitów w Rzeczypospolitej Polskiej (Dz. U. Nr 41, poz. 252 z późn. zm.), art. 11 ustawy z dnia 20 lutego 1997 r. o stosunku Państwa do Kościoła Starokatolickiego Mariawitów w Rzeczypospolitej Polskiej (Dz. U. Nr 41, poz. 253 z późn. zm.), art. 14 ustawy z dnia 20 lutego 1997 r. o stosunku Państwa do Kościoła Zielonoświątkowego w Rzeczypospolitej Polskiej (Dz. U. Nr 41, poz. 254 z późn. zm.).

32 A. Maj, Szkoła katolicka w polskim systemie szkolnictwa, „Pedagogia Christiana” 2007, t. 19, s. 126.

${ }^{33}$ A. Mezglewski, Szkolnictwo wyznaniowe $w$ Polsce $w$ latach 1944-1980. Studium historyczno-prawne, Lublin 2004, s. 7-9. 
przez kościelne jednostki organizacyjne ${ }^{34}$, rzadziej przez inne osoby prawne, takie jak np. stowarzyszenia ${ }^{35}$ czy też przez osoby fizyczne ${ }^{36}$. Szkoły katolickie w polskim prawodawstwie określane są w sposób opisowy, poprzez wskazanie na podmiot prowadzący. W art. 14 pkt 1 Konkordatu, podmiotem tym jest Kościół katolicki, natomiast w art. 20 ustawy z dnia 17 maja 1989 r. o stosunku Państwa do Kościoła Katolickiego w Rzeczypospolitej Polskiej ${ }^{37}$ - kościelne osoby prawne. Jednak w związku z tym, że zgodnie z przepisami ustawy o systemie oświaty, po spełnieniu warunków wskazanych przez prawo, szkołę prowadzić może każdy podmiot posiadający osobowość prawną, zarówno osoba fizyczna, jak i prawna, wszystkie podmioty uprawnione na mocy Kodeksu Prawa Kanonicznego do prowadzenia szkół katolickich, mogą je prowadzić w sposób legalny i szkoły te mogą być włączone w system oświaty. Warunkiem sine qua non jest posiadanie przez podmioty prawa kanonicznego osobowości prawnej również na podstawie przepisów prawa państwowego.

Osobowość prawna Kościoła katolickiego oraz sposoby jej nabywania i uznawania przez kościelne jednostki organizacyjne uregulowana jest w Konkordacie ${ }^{38}$. Kwestię tę reguluje również ustawa o stosunku Państwa do Kościoła Katolickiego, w której przewidziano trzy sposoby nabywania osobowości prawnej przez kościelne osoby prawne. Pierwszy sposób dotyczy podmiotów, które w dniu wejścia w życie ustawy posiadały kościelną osobowość prawną i zostały wymienione imiennie lub rodzajowo w art. 6-9 ustawy. Drugi sposób obejmuje podmioty rodzajowo wymienione w art. 7-9, ale utworzone po wejściu w życie ustawy. Polega on na tym, że osobowość prawna uzyskana na mocy

${ }^{34}$ J. Krukowski, Kościół i państwo. Podstawy relacji prawnych, Lublin 2000, s. 318-319; Z. Zieliński, Kościót w Polsce 1944-2002, Radom 2003, s. 439.

${ }^{35}$ Z. Zieliński, Kościół w Polsce, s. 446-447

${ }^{36}$ A. Maj, Szkoła katolicka, s. 127, 133.

${ }^{37}$ Tekst jedn. Dz. U. z 2013 r., poz. 1169 z późn. zm.

${ }^{38}$ Art. 4 Konkordatu: „1. Rzeczpospolita Polska uznaje osobowość prawną Kościoła katolickiego. 2. Rzeczpospolita Polska uznaje również osobowość prawną wszystkich instytucji kościelnych terytorialnych i personalnych, które uzyskały taką osobowość na podstawie przepisów prawa kanonicznego. Władza kościelna dokonuje stosownego powiadomienia kompetentnych organów państwowych. 3. Inne instytucje kościelne mogą na wniosek władzy kościelnej uzyskać osobowość prawną na podstawie prawa polskiego”. 
prawa kanonicznego, po stosownym powiadomieniu kompetentnych organów państwowych (ministra właściwego do spraw wyznań religijnych oraz mniejszości narodowych i etnicznych lub wojewody) ${ }^{39}$, uznana zostaje również na forum prawa państwowego. Ten sposób uznania osobowości prawnej podmiotów kościelnych wskazany został również w art. 4 ust. 2 Konkordatu. Trzeci sposób nabywania osobowości prawnej, zgodnie z art. 4 ust. 3 Konkordatu oraz art. 10 ustawy o stosunku Państwa do Kościoła Katolickiego, odbywa się w drodze rozporządzenia ministra właściwego do spraw wyznań religijnych oraz mniejszości narodowych i etnicznych ${ }^{40}$. Dotyczy on kościelnych jednostek organizacyjnych, niewymienionych w art. 6-9 ustawy oraz nieobjętych odrębną regulacją prawną ${ }^{41}$. Chodzi zatem o organizacje kościelne, erygowane przez kompetentną władzę kościelną ${ }^{42}$. Podkreślić należy,

${ }^{39}$ Powiadomienie, o którym mowa w wymienionych przepisach, sporządza się według wzoru, znajdującego się w załączniku do opracowanej przez Kościelną i Rządową Komisję Konkordatową Instrukcji dotyczącej sposobu powiadamiania organów państwowych o uzyskaniu osobowości prawnej przez terytorialne i personalne instytucje kościelne (art. 4 ust. 2 Konkordatu) oraz powiadamiania o powoływaniu i odwoływaniu osoby sprawującej funkcję organu osoby prawnej. Instrukcja ta stanowi załącznik do Obwieszczenia Ministra Spraw Zagranicznych z dnia 27 listopada 2014 r. (Dz. Urz. MSZ poz. 30). W sytuacji powstania podmiotu nieuwzględnionego w Wykazie kompetencyjnym dotyczącym powiadomienia o uzyskaniu osobowości prawnej przez instytucję kościelną należy każdorazowo przedstawić sprawę Sekretarzowi Generalnemu Konferencji Episkopatu Polski, który wyjaśni ją w porozumieniu z ministrem właściwym ds. wyznań religijnych oraz mniejszości narodowych i etnicznych oraz Nuncjuszem Apostolskim w Polsce. Nowa Instrukcja weszła w życie 1 listopada 2014 r. i zastąpiła Instrukcję z dnia 13 marca 2000 r.

${ }^{40}$ Praktyczne wytyczne zawiera Instrukcja dotycząca zakresu i sposobu uzyskania osobowości prawnej przez instytucje kościelne na podstawie prawa polskiego (art. 4 ust. 3 Konkordatu), opracowana i zatwierdzona w dniu 6 listopada 2000 r. przez Kościelną i Rządową Komisję Konkordatową, „Akta Konferencji Episkopatu Polski” 5(2000), s. 41-46.

${ }^{41}$ H. Misztal, Osobowość cywilnoprawna kościołów i innych związów wyznaniowych, w: Prawo wyznaniowe, s. 152.

${ }^{42}$ Zgodnie z kan. 312 KPK/1983 oraz pkt 5 Instrukcji dotyczącej zakresu i sposobu uzyskania osobowości prawnej przez instytucje kościelne na podstawie prawa polskiego, władzą kompetentną do erygowania stowarzyszeń publicznych jest: Stolica Apostolska dla stowarzyszeń powszechnych oraz międzynarodowych; Konferencja Episkopatu na swoim terytorium dla stowarzyszeń krajowych; biskup diecezjalny, każdy na swoim terenie, ale nie administrator diecezjalny dla stowarzyszeń diecezjalnych; inna władza kościelna, np. wyższy przełożony zakonny, na podstawie upoważnienia Stolicy Apostolskiej (na mocy przywileju apostolskiego lub własnego prawa zakonnego zatwierdzonego przez Stolicę Apostolską), 
że tego rodzaju organizacje nie podlegają ustawie z dnia 7 kwietnia 1989 r. - Prawo o stowarzyszeniach ${ }^{43}$. Z kolei wymienione w art. 35 ustawy o stosunku Państwa do Kościoła Katolickiego organizacje katolickie, zakładane za aprobatą władzy kościelnej, która zatwierdza im kapelana lub asystenta kościelnego, działające w łączności z hierarchią kościelną, mające na celu m.in. zgodną z nauką Kościoła działalność społeczno-kulturalną, oświatowo-wychowawczą i charytatywno-opiekuńczą osobowość prawną nabywają poprzez wpis do Krajowego Rejestru Sądowego, zgodnie z przepisami ustawy Prawo o stowarzyszeniach, podobnie jak organizacje, o których mowa w art. 37, zrzeszające katolików, realizujące „chrześcijańskie ideały”, jednak niepodlegające władzy kościelnej. Nabywanie osobowości prawnej w trybie art. 10 ustawy o stosunku Państwa do Kościoła Katolickiego nie dotyczy również fundacji kościelnych, które osobowość prawną uzyskują w drodze rejestracji sądowej, zgodnie z przepisami ustawy z dnia 6 kwietnia 1984 r. o fundacjach ${ }^{44}$.

Dokonując porównania statusu prawnego szkół, uznawanych za katolickie na mocy kan. $803 \S 1 \mathrm{KPK} / 1983$, ze statusem szkół tworzonych na podstawie prawa polskiego, można stwierdzić, że szkoły uznane za katolickie na podstawie prawa kanonicznego, są włączone w system oświaty, o ile tylko podmioty je zakładające posiadają osobowość cywilnoprawną oraz spełniają wymogi przewidziane przez prawo oświatowe dla mających zamiar założyć szkołę

z zastrzeżeniem kan. 312 § 2, który stanowi, że do dokonania ważnej erekcji stowarzyszenia lub jego sekcji w diecezji, chociażby się to działo mocą przywileju apostolskiego, wymagane jest pisemne zezwolenie biskupa diecezjalnego; jednakże zezwolenie udzielone przez biskupa diecezjalnego na erekcję domu instytutu zakonnego zawiera w sobie także zezwolenie na erekcję w tymże domu lub w złączonym z nim kościele stowarzyszenia, które jest właściwe temu instytutowi”. Zob. również art. 10 oraz art. 34 ustawy o stosunku Państwa do Kościoła Katolickiego; H. Misztal, Osobowość prawna kościołów i innych związków wyznaniowych, w: Prawo wyznaniowe, s. 152.

${ }^{43}$ Tekst jedn. Dz. U. z 2001 r. Nr 79, poz. 855 z późn. zm.

${ }^{44}$ Art. 7 ustawy o fundacjach (tekst jedn. Dz. U. z 1991 r. Nr 46, poz. 203 z późn. zm.) oraz pkt 4 Instrukcji dotyczącej zakresu i sposobu uzyskania osobowości prawnej przez instytucje kościelne na podstawie prawa polskiego. Do działalności fundacji założonych przez kościelne osoby prawne mają zastosowanie przepisy ustawy o fundacjach, z uwzględnieniem art. 58 ustawy o stosunku Państwa do Kościoła Katolickiego. 
osób fizycznych lub prawnych, innych niż jednostki samorządu terytorialnego.

Warto zwrócić uwagę na jeszcze jeden problem dotyczący szkół katolickich i podmiotów prowadzących. Jak to już zostało zauważone, w regulacjach prawa kościelnego oraz prawa oświatowego zakres podmiotów uprawnionych do zakładania szkół jest bardzo szeroki. Są nimi zarówno osoby fizyczne, jak i prawne. Natomiast akty normatywne regulujące stosunek Państwa do Kościoła katolickiego, jako podmioty, którym przysługuje prawo do prowadzenia szkół, wskazują: w art. 14 Konkordatu - Kościół katolicki, natomiast w art. 20 ustawy o stosunku Państwa do Kościoła Katolickiego - kościelne osoby prawne. W przepisach tych nie wymienia się szkół, prowadzonych przez inne osoby prawne czy też przez osoby fizyczne, które za zgodą biskupa uznane zostały za katolickie. Prawodawca kościelny z kolei zachęca, aby biskup diecezjalny, odpowiedzialny za szkolnictwo katolickie w diecezji, troszczył się o powstawanie szkół, w których „wychowanie jest przepojone chrześcijańskim duchem" ${ }^{45}$. Jeśli jednak w szkole uznanej formalnie przez władzę kościelną za katolicką, ale również w tej, która uważana jest za katolicką jedynie za względu na odwoływanie się do wartości chrześcijańskich, podejmowane byłyby działania lub głoszone byłyby poglądy sprzeczne z nauczaniem Kościoła, biskup nie powinien pozostawać bez reakcji. $Z$ pewnością konieczne w takiej sytuacji byłoby zwrócenie się do nauczycieli i władz szkoły ze słowami dezaprobaty, jak również informowanie i przestrzeganie wiernych przed posyłaniem dzieci do takich placówek. Niestety, wprowadzanie rodziców w błąd odnośnie do katolickiego charakteru szkół, nie podlega ocenie przez organy państwowe. Biskup nie posiada zatem środków prawnych, za pomocą których mógłby wpłynąć na zmianę zachowania nauczycieli czy władz szkoły. Może korzystać jedynie ze środków duszpasterskich. Zgoda biskupa na używanie określenia „szkoła katolicka” wymagana jest przez przepisy prawa kanonicznego, nie podlega jednak weryfikacji podczas zakładania szkoły zgodnie z przepisami prawa państwowego. W art. 20 ustawy o stosunku Państwa do Kościoła Katolickiego ustawodawca wprawdzie zwraca uwagę na zachowanie charakteru katolickie-

\footnotetext{
${ }^{45}$ Kan. 802 KPK/1983.
} 
go oraz podległość władzy kościelnej szkół, przepis ten jednak dotyczy jedynie szkół prowadzonych przez kościelne osoby prawne.

\section{ZASADY OGÓLNE ZAKŁADANIA KATOLICKICH SZKÓŁ PUBLICZNYCH I NIEPUBLICZNYCH}

Najczęściej stosowanym kryterium podziału szkół jest kryterium podmiotu prowadzącego. Na tej podstawie wyodrębnić można zasadniczo dwa rodzaje szkół: państwowe i prywatne. W polskim prawie oświatowym jednak, na mocy art. 5 ust. 1 ustawy o systemie oświaty, wyróżniono szkoły publiczne i niepubliczne, przy czym, zgodnie $\mathrm{z}$ art. 8 tej ustawy, szkoły podstawowe i gimnazja mogą być tylko szkołami publicznymi, ewentualnie niepublicznymi z uprawnieniami szkół publicznych. Szkoły niepubliczne mogą bowiem, po spełnieniu warunków określonych $\mathrm{w}$ art. 7 ust. 3 ustawy oświatowej, uzyskać status szkół niepublicznych o uprawnieniach szkół publicznych, co wiąże się z możliwością wydawania przez nie świadectw lub dyplomów państwowych. Interesujący jest fakt, że ustawa nie wprowadza ograniczeń odnośnie do podmiotów pragnących zakładać szkoły publiczne, natomiast jeśli chodzi o szkoły niepubliczne, to zgodnie z art. 5 ust. 3, ich organem prowadzącym nie mogą być jednostki samorządu terytorialnego ${ }^{46}$. Warto też podkreślić, że zakładanie szkół katolickich odbywa się na takich samych zasadach, jak zakładanie szkół przez osoby fizyczne oraz osoby prawne inne niż jednostki samorządu terytorialnego.

Założenie szkoły publicznej przez podmioty niesamorządowe, zgodnie $\mathrm{z}$ art. 58 ustawy oświatowej, wymaga przede wszystkim zezwolenia właściwego organu tej jednostki, której zadaniem własnym jest prowadzenie szkół danego typu, a w przypadku szkół artystycznych - zezwolenia ministra właściwego do spraw kultury i ochrony dziedzictwa narodowego. W celu uzyskania zezwolenia konieczne jest spełnienie warunków określonych w przepisach ustawy o systemie oświaty oraz w rozporządzeniu Ministra Edukacji Narodowej i Sportu z dnia 4

${ }^{46}$ T. Komorowski, Prawo $w$ praktyce oświatowej. Poradnik dla nauczycieli i kadry kierowniczej, Poznań 2007, s. 27. 
marca 2004 r. w sprawie szczegółowych zasad i warunków udzielania i cofania zezwolenia na założenie szkoły lub placówki publicznej przez osobę prawną lub osobę fizyczną ${ }^{47}$. Dokumenty, które należy dołączyć do wniosku, to: aktualny odpis z Krajowego Rejestru Sądowego i kopia statutu lub innego dokumentu stanowiącego podstawę funkcjonowania osoby prawnej, a w przypadku osoby fizycznej - wypis z dowodu osobistego potwierdzający imię i nazwisko oraz miejsce zamieszkania. Wraz z wnioskiem składa się również akt założycielski oraz statut szkoły, w celu zbadania ich zgodności z prawem. Ponadto, założyciel szkoły musi zapewnić odpowiednie warunki kadrowe, lokalowe, organizacyjne, wyposażeniowe, bezpieczeństwa i higieny pracy. W celu ich udokumentowania, do wniosku dołącza się wykaz nauczycieli przewidzianych do zatrudnienia w szkole oraz informację na temat ich kwalifikacji, opinię właściwego miejscowo komendanta powiatowego (miejskiego) Państwowej Straży Pożarnej i państwowego powiatowego inspektora sanitarnego o warunkach bezpieczeństwa i higieny w budynku, w którym mieścić się będzie szkoła oraz w najbliższym jego otoczeniu. Dołącza się również zobowiązanie do zapewnienia warunków działania szkoły, w tym bezpiecznych i higienicznych warunków nauki, wychowania i opieki oraz zobowiązanie do przestrzegania przepisów dotyczących szkół publicznych ${ }^{48}$. Zezwolenie na założenie szkoły publicznej wydawane jest na czas nieokreślony. Zarówno udzielenie, jak i odmowa udzielenia zezwolenia następuje w drodze decyzji administracyjnej. Rejestr wydanych zezwoleń prowadzi jednostka samorządu terytorialnego ${ }^{49}$.

W przypadku zatem zakładania szkół publicznych przez osoby fizyczne i osoby prawne niebędące jednostkami samorządu terytorialnego, w tym również przez kościelne osoby prawne, wymagane jest, zgodnie z art. 58 ustawy o systemie oświaty, sporządzenie aktu założycielskiego i uzyskanie odpowiedniego zezwolenia właściwego organu

${ }^{47}$ Dz. U. Nr 46, poz. 438 z późn. zm.

${ }^{48}$ Zob. $\S 3$ ust. 2 oraz § 4 rozporządzenia Ministra Edukacji Narodowej i Sportu z dnia 4 marca 2004 r. w sprawie szczegółowych zasad i warunków udzielania i cofania zezwolenia na założenie szkoły lub placówki publicznej przez osobę prawną lub osobę fizyczną (Dz. U. $\mathrm{Nr} 46$, poz. 438).

${ }^{49}$ Tamże $\S 5$ i $\S 6$. 
jednostki samorządu terytorialnego, natomiast jeśli chodzi o zakładanie szkół niepublicznych, to art. 82 wskazanego aktu normatywnego stanowi, że konieczny jest jedynie wpis do ewidencji prowadzonej przez jednostkę samorządu terytorialnego. Zasady zakładania szkół niepublicznych reguluje rozdział 8 tejże ustawy.

Prowadzenie ewidencji szkół niepublicznych ma zapewnić bezpieczeństwo obrotu prawnego, poprzez dostarczenie wszystkim zainteresowanym danych o podmiocie będącym organem prowadzącym, jak również o samej szkole ${ }^{50}$. Organem ewidencyjnym jest wójt (burmistrz, prezydent miasta), starosta lub marszałek województwa, czyli organy wykonawcze jednostek samorządu terytorialnego, zobowiązanych do prowadzenia odpowiedniego typu szkoły ${ }^{51}$. Zgodnie z art. 82 ust. 2 ustawy o systemie oświaty zgłoszenie do ewidencji szkół niepublicznych powinno zawierać następujące dane: oznaczenie osoby zamierzającej prowadzić szkołę, jej miejsca zamieszkania lub siedziby; określenie odpowiednio typu i rodzaju szkoły oraz daty rozpoczęcia jej funkcjonowania; wskazanie miejsca prowadzenia szkoły oraz informacje o warunkach lokalowych zapewniających możliwość prowadzenia zajęć dydaktyczno-wychowawczych i realizację innych zadań statutowych, a w przypadku szkoły prowadzącej kształcenie zawodowe - możliwość realizacji praktycznej nauki zawodu oraz bezpieczne i higieniczne warunki nauki i pracy. Do zgłoszenia dołącza się również statut szkoły, dane dotyczące kwalifikacji pracowników pedagogicznych i dyrektora, przewidzianych do zatrudnienia w szkole lub placówce oraz, w przypadku szkół, które wydawać będą świadectwa lub dyplomy państwowe, zobowiązanie do przestrzegania wymagań określonych w art. 7 ust. 3 omawianej ustawy, których spełnienie jest niezbędne do uzyskania uprawnień szkoły publicznej.

PRAWO RODZICÓW DO WYBORU SZKOŁY

Obecność szkół prowadzonych przez kościelne osoby prawne w państwowym systemie oświaty znajduje swoje uzasadnienie nie

${ }^{50}$ M. Pilich, Ustawa o systemie oświaty. Komentarz, Warszawa 2009, s. 758.

${ }^{51}$ Art. 82 ust. $1 \mathrm{w}$ zw. z art. 5e ustawy o systemie oświaty. 
tylko w prawie związków wyznaniowych do podejmowania różnorakiej, zgodnej z prawem działalności, ale również w prawie rodziców do decydowania o wychowaniu dzieci. Kościół katolicki, doceniając doniosłą rolę szkół w religijnym wychowaniu, uznaje, że pierwszymi odpowiedzialnymi za wychowanie dzieci są ich rodzice ${ }^{52}$. Prawodawstwo państwowe powinno być gwarantem z jednej strony prawa rodziców do wychowania religijnego dzieci, również przez możliwość wyboru szkoły zgodnie z ich przekonaniami, z drugiej natomiast strony prawa do zakładania i prowadzenia szkół o charakterze wyznaniowym ${ }^{53}$. Uprawnienia te sformułowane zostały w wielu dokumentach prawa międzynarodowego. W art. 5 ust. 1b Konwencji w sprawie zwalczania dyskryminacji w dziedzinie oświaty sporządzonej w Paryżu dnia 15 grudnia 1960 r. $^{54}$, wyraźnie stwierdzono, że rodzice mają prawo ,swobodnego posyłania swoich dzieci nie do państwowych, lecz do innych zakładów nauczania, odpowiadających minimalnym wymaganiom ustalonym lub zatwierdzonym przez właściwe organy oświatowe”. O prawie do wychowania dzieci zgodnie z przekonaniami religijnymi i filozoficznymi rodziców stanowi również art. 26 Powszechnej Deklaracji Praw Człowieka z dnia 10 grudnia 1948 r. ${ }^{55}$, art. 2 Protokołu nr 1 do Konwencji o ochronie praw człowieka i podstawowych wolności, sporządzony w Paryżu dnia 20 marca 1952 r. ${ }^{56}$, art. 18 ust. 4 Międzynarodowego Paktu Praw Obywatelskich i Politycznych ${ }^{57}$ oraz art. 13 ust. 3 Międzynarodowego Paktu Praw Gospodarczych, Społecznych i Kulturalnych ${ }^{58}$ otwartych do podpisu w Nowym Jorku dnia 19 grudnia 1966 r., ponadto art. 5

${ }^{52}$ Sobór Watykański II, Gravissimum educationis, n. 3; kan. 1136 KPK/1983; H. Misztal, Prawo rodziców do wychowania dzieci wedtug własnych przekonań, „,Teka Komisji Prawniczej Polskiej Akademii Nauk Oddział w Lublinie" 2009, t. 2, s. 66.

${ }^{53}$ K. Warchałowski, Szkolnictwo oraz działalność oświatowo-wychowawcza kościołów i innych zwiąków wyznaniowych, w: Prawo wyznaniowe, red. J. Krukowski, K. Warchałowski, Warszawa 2000, s. 175.

${ }^{54}$ Dz. U. z 1964 r. Nr 40, poz. 268.

${ }^{55}$ Tekst za: Prawo wyznaniowe. Wybór źródet, oprac. P. Sobczyk, Warszawa 2005, s. 23 .

${ }^{56}$ Dz. U. z 1995 r. Nr 36, poz. 175 z późn. zm.

${ }^{57}$ Dz. U. z 1977 r. Nr 38, poz. 167.

${ }^{58}$ Dz. U. z 1977 r. Nr 38, poz. 169. 
ust. 1 i 2 Deklaracji w sprawie eliminacji wszelkich form nietolerancji i dyskryminacji opartych na religii lub przekonaniach uchwalonej w Nowym Jorku dnia 25 listopada 1981 r. ${ }^{59}$ Wolności tworzenia placówek edukacyjnych oraz prawa rodziców wychowania i nauczania dzieci zgodnie z własnymi przekonaniami religijnymi, filozoficznymi i pedagogicznymi poświęcony jest także art. 14 ust. 3 Karty Praw Podstawowych Unii Europejskiej ${ }^{60}$.

Również Konstytucja RP w art. 53 ust. 3 gwarantuje rodzicom prawo do zapewnienia dzieciom wychowania i nauczania moralnego i religijnego zgodnie ze swoimi przekonaniami, a w art. 70 ust. 3 wolność wyboru dla swoich dzieci szkół innych niż publiczne. Państwo zatem poprzez stanowienie prawa, które umożliwia podmiotom niepaństwowym i niesamorządowym zakładanie szkół, realizuje gwarancje konstytucyjne, a także standardy prawa międzynarodowego. Istnienie szkół o charakterze wyznaniowym stanowi niewątpliwie odpowiedź na prawo rodziców do religijnego wychowania swoich dzieci, a w szerszym znaczeniu na prawo do realizowania wolności religijnej. Prawodawca nie pomija również prawa dziecka do wolności religijnej, które powinno być uwzględniane odpowiednio do stopnia dojrzałości dziecka. Użyte w art. 48 ust. 1 Konstytucji RP nieostre sformułowanie „stopień dojrzałości dziecka” budzi jednak wątpliwości interpretacyjne, ponieważ w polskim ustawodawstwie wiek, który stanowi granicę podejmowania przez dzieci samodzielnych decyzji odnośnie do swojego zdrowia i życia, jest niejednolity. Często granicą wiekową jest 16 lat ${ }^{61}$ (np. do zawarcia małżeństwa przez kobietę niepełnoletnią ${ }^{62}$, zatrudnienia młodocianego na podstawie umowy o pracę $^{63}$ ), ale są sytuacje, w których wystarczy ukończenie 13. roku życia (np. prawo uczestnic-

${ }^{59}$ Tekst za: Prawo wyznaniowe. Wybór źródet, s. 39.

${ }^{60}$ Dz. Urz. UE 2012/C 326/02, s. 398.

${ }^{61} \mathrm{M}$. Bielecki, Wychowanie dziecka zgodnie z przekonaniami rodziców oraz jego wolność religijna $w$ kontekście orzeczenia Europejskiego Trybunału Praw Człowieka z 3 listopada 2009, w: Szkoła. Edukacja i wychowanie, red. A. Balicki, T. Guz, W. Lis, Lublin 2010, s. 46-47.

${ }^{62}$ Art. $10 \S 2$ ustawy z dnia 25 lutego 1964 r. - Kodeks rodzinny i opiekuńczy (tekst jedn. Dz. U. z 2012 r., poz. 788 z późn. zm.).

${ }^{63}$ Art. 65 ust. 3 Konstytucji RP. 
twa $\mathrm{w}$ postępowaniu sądowym na prawach strony ${ }^{64}$ ). Przede wszystkim jednak należy pamiętać, że dzieci podlegają władzy rodzicielskiej i jedynie w przypadkach określonych w ustawie i tylko na podstawie prawomocnego orzeczenia sądu ${ }^{65}$ rodzice mogą być pozbawieni tych praw $^{66}$. W przypadku zaistnienia konfliktu pomiędzy prawem rodziców do religijnego wychowania dzieci a wolnością religijną dzieci, pierwszym i podstawowym sposobem jego rozwiązania powinna być droga dialogu, a w ostateczności ingerencja sądu ${ }^{67}$.

\section{PODSUMOWANIE}

Reasumując należy stwierdzić, że możliwość wyboru szkoły, w której wychowanie odbywa się zgodnie z przekonaniami religijnymi rodziców, stanowi konkretny przejaw realizacji wolności religijnej w państwie. Odpowiedzią na potrzeby obywateli powinno być zatem takie stanowienie prawa, aby szkoły wyznaniowe mogły być swobodnie zakładane i prowadzone. W regulacjach prawa oświatowego w Polsce nie wyodrębnia się szkół prowadzonych przez podmioty kościelne. Co do zasady w odniesieniu do tego rodzaju szkół stosuje się przepisy ogólne, przewidziane dla osób prawnych niebędących jednostkami samorządu terytorialnego oraz osób fizycznych.

Szkoły katolickie, od wieków wpisane w polski system oświaty, nieustannie powinny zabiegać o wysokie standardy nauczania, przede wszystkim jednak powinny troszczyć się o zachowanie swej wyznaniowej tożsamości, która stanowi o ich specyfice. Władze państwowe i samorządowe natomiast powinny popierać działalność oświatową

${ }^{64}$ Art. 12 i art. 15 ustawy z dnia 23 kwietnia 1964 r. - Kodeks cywiny (Dz. U. Nr 16, poz. 93 z późn. zm.); art. $573 \S 1$ ustawy z 17 listopada 1964 r. - Kodeks postępowania cywilnego (Dz. U. Nr 43, poz. 296 z późn. zm.).

${ }^{65}$ P. Sobczyk, Wolność religijna $w$ działalności orzeczniczej Trybunału Konstytucyjnego, w: Prawo wyznaniowe w Polsce (1989-2009). Analizy - dyskusje - postulaty, red. D. Walencik, Katowice-Bielsko-Biała 2009, s. 75.

${ }^{66}$ Art. 48 ust. 2 Konstytucji RP.

${ }^{67}$ A. Łopatka, Dziecko. Jego prawa człowieka, Warszawa 2000, s. 80-81. 
związków wyznaniowych, zgodnie z konstytucyjną zasadą współpracy dla dobra człowieka i dobra wspólnego ${ }^{68}$.

\section{BIBLIOGRAFIA}

Bielecki M., Wychowanie dziecka zgodnie z przekonaniami rodziców oraz jego wolność religijna w kontekście orzeczenia Europejskiego Trybunału Praw Człowieka z 3 listopada 2009, w: Szkoła. Edukacja i wychowanie, red. A. Balicki, T. Guz, W. Lis, Lublin 2010, s. 37-50.

Chiappetta L., Il Codice di Diritto Canonico. Commento giuridico-pastorale, Napoli 1988.

Composta D., Commento al can. 803, w: Commento al Codice di Diritto Canonico, red. P.V. Pinto, Città del Vaticano 2001.

Composta D., Commento al can. 806, w: Commento al Codice di Diritto Canonico, red. P.V. Pinto, Città del Vaticano 2001.

Dmowski S., Komentarz do art. 8 ( $n r$ 1), w: Komentarz do kodeksu cywilnego. Księga pierwsza. Cześć ogólna. Tytut II. Osoby, red. S. Dmowski, S. Rudnicki, Warszawa 2004, s. 66-71.

Komorowski T., Prawo $w$ praktyce oświatowej. Poradnik dla nauczycieli i kadry kierowniczej, Poznań 2007.

Krukowski J., Kościót i państwo. Podstawy relacji prawnych, Lublin 2000.

Kurzyna-Chmiel D., Podstawy prawne i organizacyjne oświaty. Prawo oświatowe $w$ zarysie, Warszawa 2009.

Łopatka A., Dziecko. Jego prawa człowieka, Warszawa 2000.

Maj A., Szkoła katolicka w polskim systemie szkolnictwa, „Pedagogia Christiana" 2007, t. 19, s. 125-136.

Mezglewski A., Szkolnictwo wyznaniowe w Polsce w latach 1944-1980. Studium historyczno-prawne, Lublin 2004.

Misztal H., Prawo rodziców do wychowania dzieci wedtug własnych przekonań, ,Teka Komisji Prawniczej Polskiej Akademii Nauk Oddział w Lublinie" 2009, t. 2, s. 64-75.

Mezglewski A., Misztal H., Stanisz P., Prawo wyznaniowe, Warszawa 2011.

Pilich M., Ustawa o systemie oświaty. Komentarz, Warszawa 2009.

${ }^{68}$ Art. 25 ust. 3 Konstytucji RP. 
Sobański R., Osoby fizyczne i prawne, w: Komentarz do Kodeksu Prawa Kanonicznego. Tom I. Księga I. Normy ogólne, red. J. Krukowski, R. Sobański, Poznań 2003, s. 163-201.

Sobczyk P., Wolność religijna $w$ działalności orzeczniczej Trybunatu Konstytucyjnego, w: Prawo wyznaniowe w Polsce (1989-2009). Analizy-dyskusje

- postulaty, red. D. Walencik, Katowice-Bielsko-Biała 2009, s. 67-80.

Warchałowski K., Nauczanie religii i szkolnictwo katolickie $w$ konkordatach wspótczesnych, Lublin 1998.

Warchałowski K., Szkolnictwo oraz działalność oświatowo-wychowawcza kościołów i innych związów wyznaniowych, w: Prawo wyznaniowe, red. J. Krukowski, K. Warchałowski, Warszawa 2000, s. 161-186.

Wroceński J., Sytuacja prawna szkolnictwa wyznaniowego w III Rzeczypospolitej Polskiej, w: Ecclesia et status. Księga jubileuszowa z okazji 40-lecia pracy naukowej Profesora Józefa Krukowskiego, red. A. Dębiński, K. Orzeszyna, M. Sitarz, Lublin 2004, s. 961-982.

Zasępa T., Szkoła katolicka w XXI wieku, w: Szkoła katolicka w XXI wieku, red. T. Zasępa, Lublin 2003, s. 9-19.

Zieliński Z., Kościół w Polsce 1944-2002, Radom 2003.

\section{THE RIGHT OF THE CATHOLIC CHURCH TO SETTING UP AND RUNNING OF SCHOOLS}

\section{Summary}

The article presented were the basic reasons for the Catholic Church's educational activities. Referring to the centuries-old tradition Church bodies also now are pursuing educational establishments, among which deserve special attention of school With guaranteed by the legislation of the democratic States of religious freedom, the Church supports parents in the upbringing of children in accordance with their religious beliefs. A special form of this aid to schools, in which tutorial is based on Christian values.

Catholic schools are subject to the dual legal regime. The establishment and the basic principles of their operation specifies both the legislation and the teaching of the Church, as well as the provisions of national law. In the Polish education system with regard to the schools run by the Church legal entities as a general rule, apply the provisions relating to schools run by individuals 
and legal persons, other than the units of local government. Church entities which are legal persons may, in accordance with Polish law, established public schools, non-public to power public schools and non-public. It is important that in its efforts aimed at the implementation of the requirements arising from government legislation not to forget as earnestly care about preserving Catholic identity that provides for the specific characteristics of these schools.

\section{Ttumaczenie: Aneta M. Abramowicz}

Key words: Catholic school, school operators, the upbringing of children in accordance with the beliefs of parents

Słowa kluczowe: szkoła katolicka, podmioty prowadzące szkołę, wychowanie dzieci zgodnie z przekonaniami rodziców 